\title{
Patterns of larval distribution and settlement of Concholepas concholepas (Bruguiere, 1789) (Gastropoda, Muricidae) in fjords and channels of southern Chile
}

\author{
Patrones de distribución de larvas y asentamiento de Concholepas concholepas (Bruguiere, \\ 1789) (Gastropoda, Muricidae) en fiordos y canales del sur de Chile
}

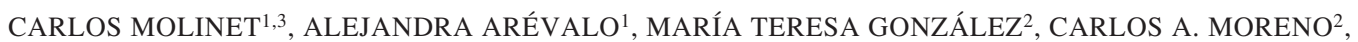 \\ JAVIER ARATA ${ }^{2} \&$ EDWIN NIKLITSCHEK ${ }^{1}$
}

\author{
${ }^{1}$ Centro Universitario de la Trapananda e ${ }^{2}$ Instituto de Ecología y Evolución, ${ }^{3}$ Instituto de Acuicultura, Universidad Austral \\ de Chile, Casilla 567, Valdivia, Chile; e-mail: cmolinet@uach.cl
}

\begin{abstract}
The distribution of Concholepas concholepas (Mollusca, Gastropoda, Muricidae) is limited to the coasts of Chile and southern Peru. Almost all studies of this gastropod have been carried out in open coastal systems, rather than the fjords and channels of southern Chile, despite the fact that this area represents ca. $95 \%$ of the total coastline in this country. Although there is a large volume of background literature on C. concholepas, almost nothing is published about early larval development under natural conditions, mostly because early veligers have rarely been found in nature. This study is the first attempt to determine the spatial and temporal abundance and size patterns of $C$. concholepas larvae in their natural environment throughout all of their developmental stages until they settle. Weekly plankton samples were obtained at the surface and at $8 \mathrm{~m}$ depth in four locations in southern Chile in combination with temperature and salinity records in each location. Settlement was quantified using artificial substrates in all locations. We have observed that C. concholepas larval development occurs throughout the entire year in Chilean inland seas, with early veliger larvae being released mostly from August to March, reaching the competent stage around June to August, and settling between July and August. Thus, larvae appear to have a long planktonic development that can last between 6 and 12 months. Differences in local hydrology could affect larval development of $C$. concholepas in this region. Further oceanographic and ecological investigation is necessary in order to answer the questions and hypotheses originated from this study.
\end{abstract}

Key words: larval ecology, larval development, veliger larvae, fjords and channels, C. concholepas.

\section{RESUMEN}

Concholepas concholepas (Mollusca, Gastropoda, Muricidae) se distribuye entre las costas del sur de Perú y extremo sur de Chile. Prácticamente todos los estudios sobre este gastrópodo han sido realizados en costas expuestas, sin considerar los fiordos y canales del sur de Chile, a pesar de que estos representan aproximadamente el $95 \%$ de la línea costera de este país. Aunque se ha publicado un importante volumen de literatura sobre $C$. concholepas, existen escasos antecedentes acerca de su desarrollo larval temprano en condiciones naturales, principalmente debido a que estos estadios han sido escasamente recolectados en la naturaleza. Este estudio es el primer intento por determinar los patrones de abundancia espacial y temporal de larvas de $C$. concholepas a través de su desarrollo hasta el asentamiento, en su ambiente natural. Para ello, fueron recolectadas muestras de plancton semanalmente en superficie y $8 \mathrm{~m}$ de profundidad en cuatro canales del sur de Chile. Temperatura y salinidad fueron registradas simultáneamente en cada sector. El asentamiento fue cuantificado usando un sustrato artificial en los cuatro sectores. En este estudio se observó que el desarrollo larval de $C$. concholepas ocurre durante todo el año en las aguas interiores del sur de Chile, observándose estados tempranos principalmente entre agosto y marzo, estados competentes entre junio y agosto, y asentamiento entre julio y agosto. Así, C. concholepas parece tener un largo periodo de desarrollo larval cuya duración fue estimada entre 6 a 12 meses en este estudio. Finalmente se sugiere que la hidrología local puede afectar el desarrollo larval de C. concholepas en esta región. Nuevas investigaciones oceanográficas y ecológicas son necesarias para responder las interrogantes e hipótesis surgidas de este estudio.

Palabras clave: ecología larval, desarrollo larval, larva veliger, fiordos y canales, C. concholepas. 


\section{INTRODUCTION}

The patterns of larval development in marine invertebrates could respond to constraints that are present throughout the developmental process (Levin \& Bridges 1995) and are strongly influenced by environmental conditions (Thorson 1950). At least six sources of physiological stress may affect larval development, such as extreme or variable temperatures and salinities, low dissolved oxygen, pollution, ultraviolet radiation, and poor nutrition, which could be more evident at the limits of species distributions (Morgan 1995). Episodic settlement events have led to the belief that various sources of mortality overwhelm larvae (Thorson 1950, Johnson \& Shanks 2003). It has also been suggested that settlement processes could be strongly affected by oceanographic features (Pineda 1991, Shanks 1995, Pineda 1999). Furthermore, there could be different larval responses for the same species in different geographical regions due to the responses of different traits to environmental variation (Panfili et al. 2004), which could affect patterns of larval distribution.

Concholepas concholepas (Bruguiere, 1789) Gastropoda, Muricidae, is a key benthic species along the entire Chilean coast (Stuardo 1979, Castilla \& Durán 1985, Moreno et al. 1986), which has been commercially exploited for the last 25 years (Leiva \& Castilla 2002). Their development involves an embryonic intracapsular stage, a planktonic larval stage, and a final epineustonic competent veliger larval stage. Newly hatched larvae are about 180-255 $\mathrm{mm}$ in length and are released from spring to autumn (Gallardo 1973, Pinto et al. 1993). Larval development in $C$. concholepas lasts for 3 months under laboratory conditions (Disalvo 1988), suggesting a high dispersal potential for this species, according to Scheltema's hypothesis (Levin \& Bridges 1995). However, early veliger stages have rarely been recorded in the plankton (Moreno et al. 1993, Peña et al. 1994), which has led to the suggestion that their development may occur in deeper waters (Moreno et al. 1993).

In contrast, competent larvae (Disalvo 1988) are found forming aggregations in surface waters (Disalvo \& Carriker 1994) from autumn to spring along the south central, open coast of Chile (Moreno et al. 1993, Peña et al. 1994,
Poulin et al. 2002a). Settlement of $C$. concholepas has been observed in the intertidal zone (Reyes \& Moreno 1990, Stotz et al. 1991, Moreno et al. 1993), temporally in concordance with the presence of competent veliger larvae in the water (Moreno et al. 1993, Martínez \& Navarrete 2002). Newly settled individuals have also been observed on shells of conspecific adults in the shallow subtidal zone (Manríquez et al. 2004), as well as forming aggregations in the low intertidal zone (Stotz et al. 1991).

Although $C$. concholepas has been the subject of intensive studies in the last 20 years, its larval development under natural conditions remains poorly understood. Also, almost all studies of this gastropod have been carried out in open coastal systems, excluding the inland seas of Chile, despite the fact that this inland coastline represents ca. $95 \%$ of this country's total (SHOA 2002). A characteristic feature of inland seas is a well-defined pycnocline (Pickard 1971, Silva et al. 1995), which would have an important effect on the larval distribution and development of this species.

The objectives of this study were: (a) to describe the development of $C$. concholepas from early and late veliger larval stages, to post larval settler stages, analyzing their abundance and size patterns throughout an entire annual cycle, and (b) to assess the effects of environmental variables, such as salinity and temperature, on these patterns. These objectives were addressed through: (a) weekly plankton collections, (b) monthly settlement samples from artificial substrata, and (c) by analyzing these data in combination with records of temperature and salinity, which were recorded at four localities in Chile's inland seas during an annual cycle. The results suggest that $C$. concholepas free swimming larval stages occur throughout the year in Chilean inland seas, with a long planktonic larval development that could last between 6 and 12 months. Differences in local hydrology could affect larval development and distribution in this region.

\section{MATERIAL AND METHODS}

\section{Study area and periods}

This investigation was undertaken between September 2000 and December 2001 in four 
locations: Raúl Marín Balmaceda (hereafter referred to as RMB) (4346'18" S, 730' $13^{\circ}$ "

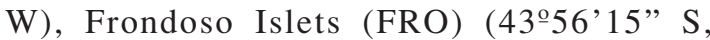
7303'13" W), Refugio channel close to Melipichún Point (MEL) (435ㄱ3” S, 7307'16" W), and Gala Islands (GAL)

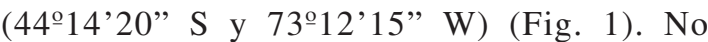
samples were collected at GAL in September 2001.

\section{Data collection}

Diurnal plankton samples (taken between midday and sunset) were collected weekly at the surface and at $8 \mathrm{~m}$ depth in the four study areas ( \pm 2 days between areas), normally during flood tide to reduce the effects of flow variations caused by tidal forcing. These depths were chosen because competent larvae have been found in surface samples, and because the pycnocline is usually found around $6 \mathrm{~m}$ depth in these channels. Samples were obtained by simultaneously towing two plankton nets $(2 \mathrm{~m}$ long, sections of $0.8 \times 0.4 \mathrm{~m}$, with $250 \mu \mathrm{m}$ mesh size) for ca. $1,000 \mathrm{~m}$ (demarked at the coastline), between 50-100 m from the shore. Surface samples were collected from the upper $30 \mathrm{~cm}$. The net was kept at the surface with the aid of lateral floats and was towed parallel to the boat. The net was maintained at $8 \mathrm{~m}$ depth by adjusting the length and inclination angle of the towed rope. Collected plankton was

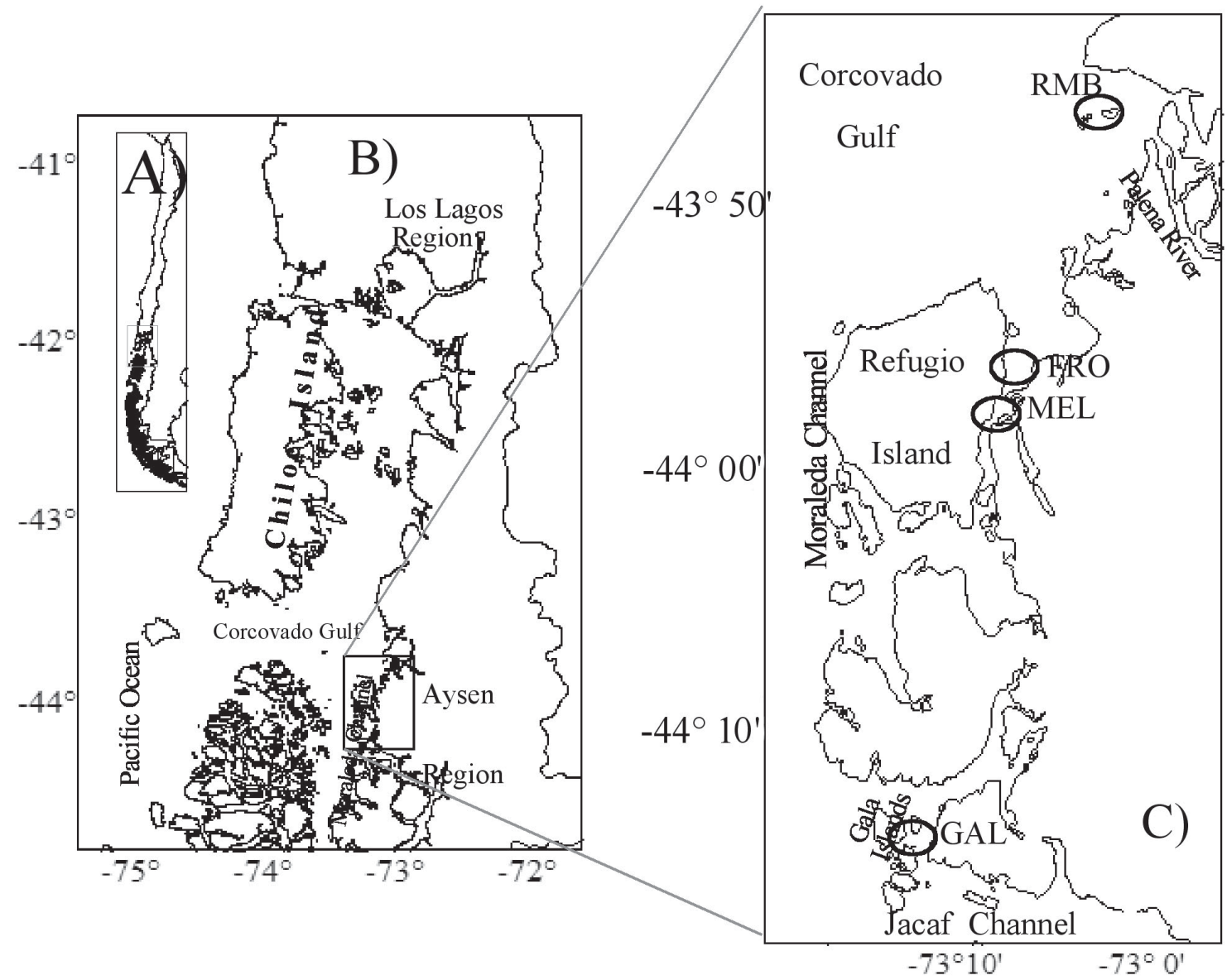

Fig. 1: (A) Study area in southern Chile (gray rectangle). (B) A portion of the inland seas of southern Chile, showing the study area at southeast of Chiloé Island (black rectangle). (C) Specific study area, the four localities where samples were collected are circled on the right panel (RMB, Raúl Marín Balmaceda; FRO, Frondoso; MEL, Melipichún; GAL, Gala). Gray lines linking Fig. 1B and $1 \mathrm{C}$ are showing the extended study area (rectangle in Fig. 1B).

Área de estudio en el sur de Chile. En el panel de la derecha encerradas en círculos se muestran las cuatro localidades donde se recolectaron las muestras (RMB, Raul Marín Balmaceda; FRO, Frondoso; MEL, Melipichún; GAL, Gala). 
gathered in 2 L bottles, sieved through a 100 $\mu \mathrm{m}$ mesh, preserved with $70 \%$ ethanol, and stored in $500 \mathrm{~mL}$ flasks for further analysis in the laboratory.

All veliger larvae contained in the $500 \mathrm{~mL}$ samples were identified, separated and counted using a Motic stereomicroscope at $80 \mathrm{x}$, and measured with a 10x graduated ocular with an accuracy of $12.5 \mu \mathrm{m}$. The total volume filtered in each sample was estimated by multiplying the dimensions of the net mouth by the distance traveled. Larval abundance was calculated by dividing the total number of larvae by the total volume of water filtered through the net.

During each sampling period, temperature and salinity were recorded at the surface and 8 $m$ depth from water samples collected with a vertical sampling bottle at the beginning and end of the sampling. Temperature was recorded using an alcohol thermometer accurate to \pm $0.25{ }^{\circ} \mathrm{C}$ and salinity was recorded using a Beto refractometer with \pm 1 psu precision (Emery \& Thomson 1997). Both the thermometer and the refractometer were calibrated monthly with a Horiba u10 water analyzer.

Settlement was evaluated using a plastic transparent sheet of $0.55 \times 0.3 \mathrm{~m}$ and $2 \mathrm{~mm}$ thickness. Preliminary observations showed that this kind of plaque were colonized by benthic organisms similar to those observed in the intertidal zone where recruitment of $C$. concholepas occurred; this coincides with the observations made by Reyes \& Moreno (1990) and Disalvo \& Carriker (1994). Each settlement plaque was made by putting together three sheets, separated by $5-\mathrm{cm}$ pieces of plastic placed in the junctions of the sheets and held together with adjustable plastic bands (buckle bands). The plaques were conditioned from November to December 2000 in Santo Domingo by suspending them at $1 \mathrm{~m}$ depth from a $100 \mathrm{~m}$ long line, anchored at around 40 $\mathrm{m}$ depth. The conditioning of the plaques included their colonization for benthic microalgae, Cirripedia, and Mitilidae, the latter of which almost entirely covered the plaques by the end of the study. During January 2001, 30 plaques (randomly chosen) were installed at each location (at the surface, 0.5 and $8 \mathrm{~m}$ depth), each one independently and randomly distributed on a long line with both ends anchored on the coast. Settlement on the plaques was monitored monthly, except for
July, by cutting the buckle bands, observing each sheet, and returning them to the water.

\section{Data analysis}

Larvae and post larvae were grouped in categories according to their particular developmental stage: (a) early veliger (EV) larvae, without pre-metamorphic lips, between 250 and $1300 \mu \mathrm{m}$ in length (Disalvo 1988); (b) competent veliger (CV) larvae, with premetamorphic lips larger than 1,300 $\mu \mathrm{m}$ (Disalvo 1988); (c) settlers (S) (Connell 1985), post-metamorphic individuals with visible deposition of teleoconch, smaller than $3 \mathrm{~mm}$ (Disalvo 1988).

Due to the low numbers of CV larvae and settlers collected during this study, only univariate analyses were applied to these stages. Because each sampling location had different hydrological conditions, larval abundances, larval sizes, and settler abundances were compared among locations, using the univariate non-parametric Kruskal-Wallis test (with a posteriori Dunn test). This same test was used in order to assess the seasonal development of $C$. concholepas larvae, comparing larval abundances and sizes among months. To compare larval abundances and sizes between the surface and $8 \mathrm{~m}$ depth, the Mann-Whitney U-test was used (Zar 1999). The relationships between salinity and temperature versus EV abundances and sizes were studied using the Spearman $\left(\mathrm{r}_{\mathrm{s}}\right)$ correlation. Finally a Generalized Linear Model (GLM) was applied to discriminate the variable (s) that significantly explained distributions of larval sizes, assuming a normal distribution and a link function identity $(\mu)$ for evaluating the response variable. Because of net selectivity, larval size data were standardized in reference to the mode and individuals $<342 \mu \mathrm{m}$ were not considered in the analysis. Likewise, due to the different quantity of larvae collected in each sample, means of larval size were weighted using the standard error ${ }^{-1}$. Also, due to the nonnormal distribution of larval abundances, a GLM was applied to discriminate the variable (s) that significantly explained distributions of larval abundances, assuming a Poisson distribution and a link function $\log$ for evaluating the response variable. For both, larval sizes and larval abundances, the 
explanatory variables used were: depth, locality, month, temperature, salinity and all their interactions. The inclusion of each factor most linked to the response variable was determined by using Deviance analysis. The significance of each factor was determined using a $\chi^{2}$ test (Venables \& Ripley 1998). Because month - temperature and depth-salinity were auto-correlated $(r>0.35)$, the final model of larval abundance included only month and depth, while the larval size model included temperature, salinity, and location. For each model those variables were selected that explained a higher percentage of the deviance.

\section{RESULTS}

\section{Larval abundance}

A total of 13,035 larvae were collected from 395 samples taken between September 2000 and December 2001. Larvae were found in 58 $\%$ of the samples. Ninety nine percent of collected larvae were $\mathrm{EV}$, and $1 \%$ were $\mathrm{CV}$ larvae. EV larval abundance ranged between
0.002 and 2.96 larvae $\mathrm{m}^{-3}$, and $\mathrm{CV}$ larval abundance ranged between 0.01 and 0.15 larvae $\mathrm{m}^{-3}$. Month and depth showed significant effects on EV larval abundance, explaining 47 $\%$ of the residual deviance in the GLM analyses (Table 1). EV larvae were found at the surface as well as at $8 \mathrm{~m}$ depth in the four study areas. However, larval abundance was significantly higher at $8 \mathrm{~m}$ depth in all locations but GAL (Table 2). However larval abundance at $8 \mathrm{~m}$ depth could be underestimate because recent observations of water filtered using flow meters at surface and $8 \mathrm{~m}$ depth in Refugio Channel shown that the net filtered a significantly higher water volume at the surface than at the 8 $\mathrm{m}$ depth (C. Molinet, unpublished data).

Analysis by month showed significant differences among all of the locations (Kruskal-Wallis test, RMB: $\mathrm{H}_{11,90}=30, \mathrm{P}=$ 0.001; FRO: $\mathrm{H}_{11,122}=50.3, \mathrm{P}<0.0001$; MEL: $\mathrm{H}_{11,171}=76.3, \mathrm{P}<0.0001 ;$ GAL: $\mathrm{H}_{11,120}=$ $31.2, \mathrm{P}=0.001$ ), with higher abundances from September to January and lower abundances from May to August (Fig. 2). EV larval abundance was intermediate from February to April.

TABLE 1

Results of the sequential deviance analysis for the response variable EV larval abundance of $C$. concholepas. Variables are month and depth

Resultados del análisis de desvianza secuencial para la variable respuesta: abundancia de larvas tempranas. Las variables son mes y profundidad

\begin{tabular}{lccccc}
\hline Term & Degrees of freedom & Residual deviance & Degrees of freedom & Residual deviance & P-Value \\
\hline Null & & & 394 & 143.1689 & $<0.05$ \\
Month & 12 & 62.5 & 382 & 80.6 & $<0.05$ \\
Depth & 1 & 4.2 & 381 & 76.4 & $<$ \\
\hline
\end{tabular}

TABLE 2

Median of $C$. concholepas EV larvae abundance found at the surface and at $8 \mathrm{~m}$ depth at each location; $\mathrm{N}$ = sampled number; $\mathrm{U}=$ Mann-Whitney U-statistic; $\mathrm{P}=$ probability

Mediana de las abundancias de larvas tempranas de $C$. concholepas encontradas en superficie y $8 \mathrm{~m}$ de profundidad en cada sector; $\mathrm{N}$ = número de muestras; $\mathrm{U}=$ Estadígrafo de Mann-Whitney, $\mathrm{P}=$ Valor de probabilidad

\begin{tabular}{|c|c|c|c|c|c|c|}
\hline \multirow[t]{2}{*}{ Location } & \multicolumn{2}{|c|}{ Median } & \multicolumn{2}{|c|}{$\mathrm{N}$} & \multirow[t]{2}{*}{ U-value } & \multirow[t]{2}{*}{ P-value } \\
\hline & Surface & $8 \mathrm{~m}$ & Surface & $8 \mathrm{~m}$ & & \\
\hline RMB & 0.000 & 0.014 & 58 & 58 & 1278 & 0.025 \\
\hline FRO & 0.000 & 0.039 & 62 & 62 & 1397 & 0.017 \\
\hline MEL & 0.000 & 0.033 & 63 & 63 & 1381 & 0.005 \\
\hline GAL & 0.006 & 0.009 & 57 & 57 & 1464 & 0.230 \\
\hline
\end{tabular}



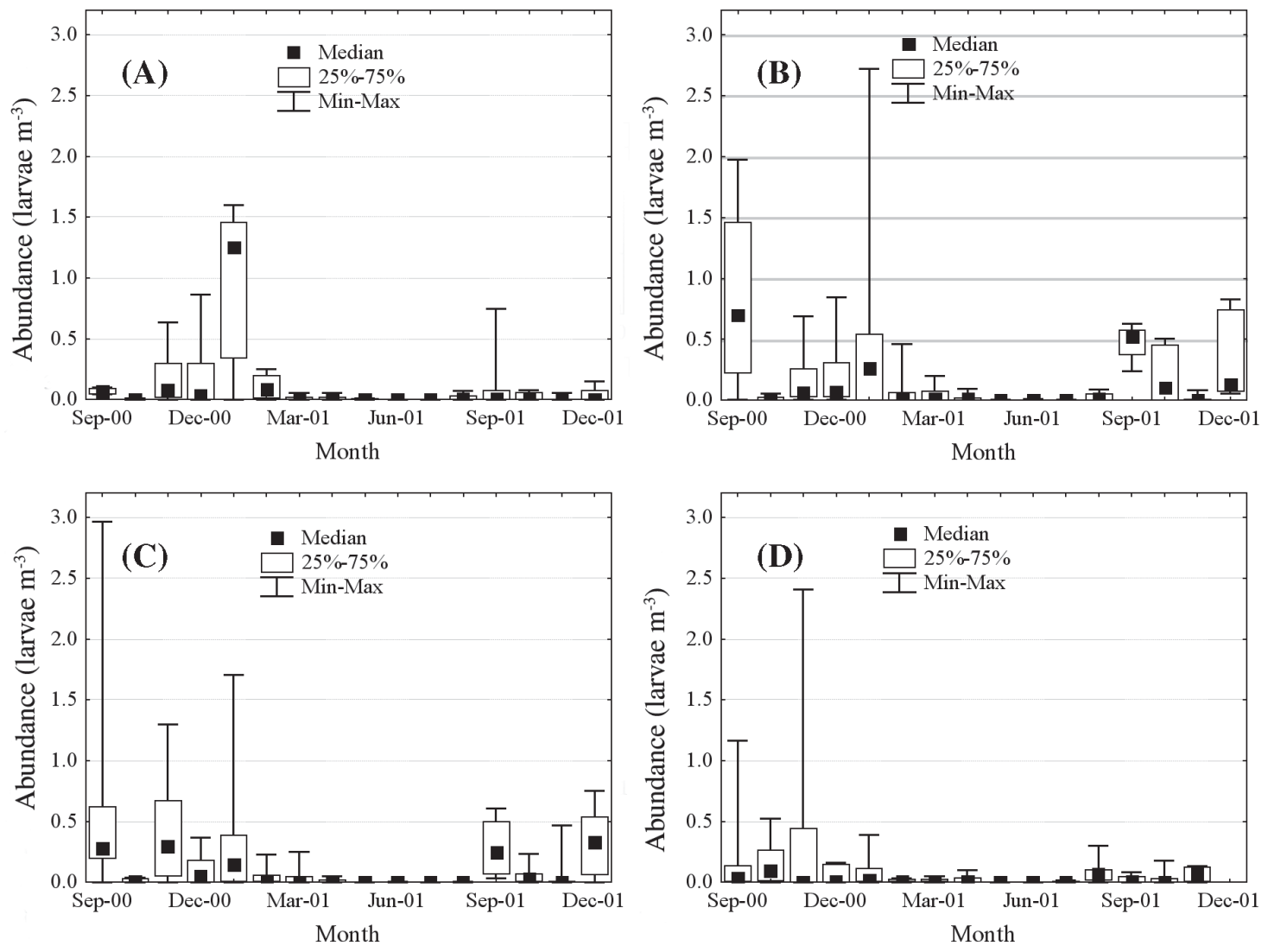

Fig. 2: Monthly abundance values of $C$. concholepas EV larvae at: (A) RMB, (B) FRO, (C) MEL and (D) GAL.

Valores de abundancias mensuales de larvas tempranas de C. concholepas en: (A) RMB, (B) FRO, (C) MEL and (D) GAL.

CV larvae were found mainly at the surface (93\%) in all the study areas, except at RMB where no CV larvae were found. Significant differences in CV larval abundances were observed among locations (Kruskal-Wallis test, $\mathrm{H}_{2,23}=13.1, \mathrm{P}=0.004$ ), with MEL and GAL having higher abundances and FRO having lower abundances (Fig. 3). CV larvae were only found from June to August in 2001, with abundance peaks in July at MEL and FRO, while at GAL abundance decreased from June to August (Fig. 3). However, differences among months were not significant (Kruskal-Wallis test, MEL: $\mathrm{H}_{2,5}=0.6$, $\mathrm{P}=0.74$; GAL: $\left.\mathrm{H}_{2,8}=0.88, \mathrm{P}=0.64\right)$. Due to their scarcity, the data for CV larvae in FRO could not be statistically analyzed.

\section{Larval size}

Analysis of the frequencies of observed sizes during the entire study period showed a unimodal tendency with clear predominance of small EV larvae (300 to $700 \mu \mathrm{m}$ ) (Fig. 4). Occurrence of intermediate EV larvae (725 to $1,000 \mu \mathrm{m})$ was infrequent, and occurrence of large EV larvae $(>1,000 \mu \mathrm{m})$ was rare, while CV larvae were infrequent (Fig. 4). The range of EV larval sizes varied between 210 and 1,199 $\mathrm{mm}$ (median $=377.12 \mu \mathrm{m})$, while CV larval sizes ranged between 1,097 and 2,143 $\mu \mathrm{m}$ (median $=1,714 \mu \mathrm{m})$. Temperature, salinity, location and their interactions had significant effects on EV larval sizes, although these variables together explained only ca. $30 \%$ of the residual deviance (Table 3). EV larvae were significantly larger in surface waters at all locations, except at RMB (Table 4). Likewise, EV larval sizes were significantly different among locations (Kruskal-Wallis test, $\mathrm{H}_{3,12957}=$ $637, \mathrm{P}<0.05)$, with the largest ones found at GAL (median $=400 \mu \mathrm{m}$ ), followed by RMB (median $=375 \mu \mathrm{m})$, MEL, and FRO (in both 

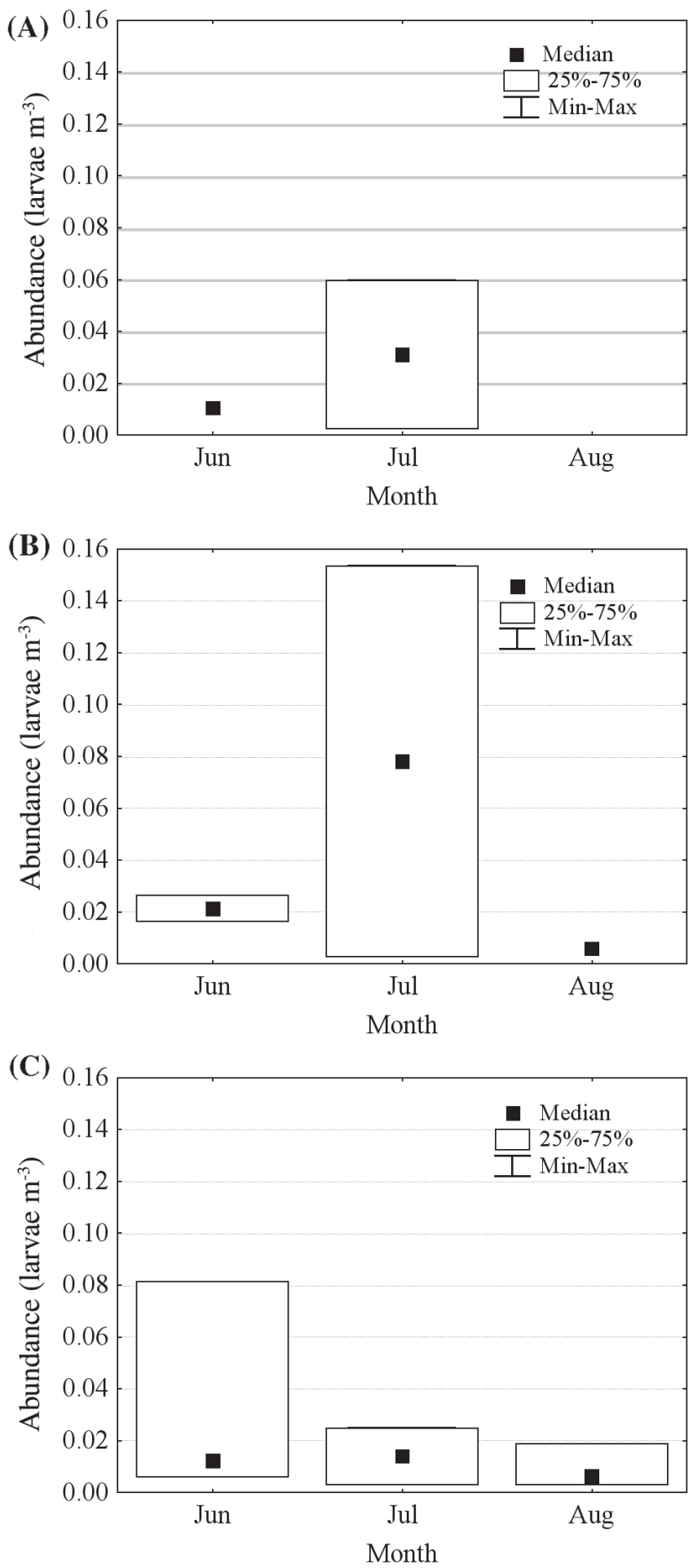

Fig. 3: Monthly abundance values of $C$. concholepas $\mathrm{CV}$ larvae at three locations; (A) FRO, (B) MEL, and (C) GAL.

Valores de abundancias mensuales larvas $\mathrm{CV}$ de $C$. concholepas en tres localidades: (A) FRO, (B) MEL y (C) GAL. 


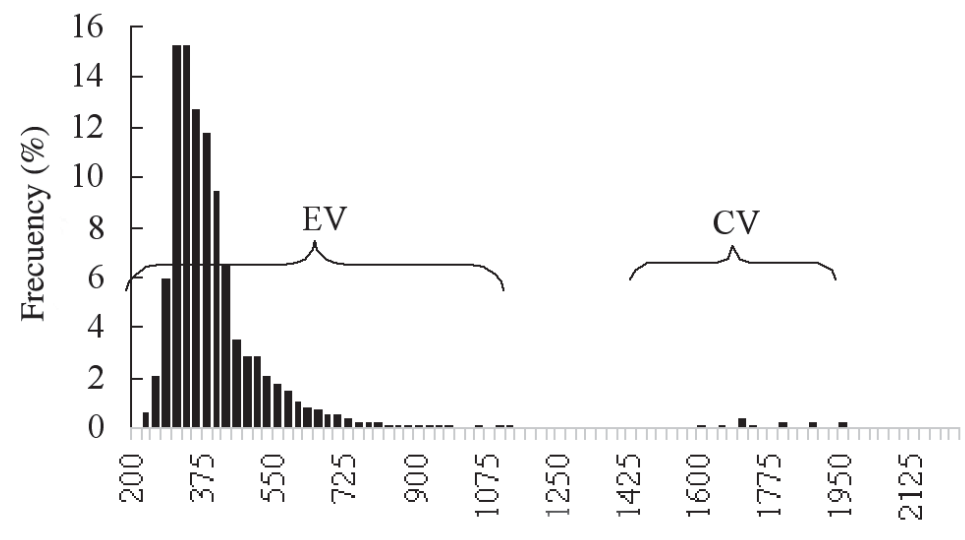

Length (um)

Fig. 4: Frequencies of sizes classes of all C. concholepas veliger larvae collected during the study period in all the study areas. EV, early veliger; CV, competent veliger.

Estructura de tallas de larvas veliger de $C$. concholepas recolectadas durante el periodo de estudio en todas las áreas de estudio. VT veliger tempranas; $\mathrm{VC}$, veliger competentes.

TABLE 3

Results of the sequential deviance analysis for the response variable EV larvae sizes of $C$. concholepas. Variables are salinity, temperature, location and their interactions

Resultados del análisis de desvianza secuencial para la variable respuesta: tallas de larvas tempranas de C. concholepas. Las variables son salinidad, temperatura, localidad y sus interacciones

\begin{tabular}{|c|c|c|c|c|c|}
\hline Term & $\begin{array}{l}\text { Degrees of } \\
\text { freedom }\end{array}$ & $\begin{array}{l}\text { Deviance } \\
\text { residuals }\end{array}$ & $\begin{array}{l}\text { Degrees of } \\
\text { freedom }\end{array}$ & $\begin{array}{l}\text { Residual } \\
\text { deviance }\end{array}$ & P-Value \\
\hline NULL & & & 150 & 486473 & \\
\hline Location & 3 & 9744 & 147 & 476729 & $<0.05$ \\
\hline Temperature & 1 & 81305 & 146 & 395423 & $<0.05$ \\
\hline Salinity & 1 & 2153 & 145 & 393270 & $<0.05$ \\
\hline Location * salinity & 3 & 6427 & 142 & 386842 & $<0.05$ \\
\hline Locations *temperature & 3 & 25663 & 138 & 358603 & $<0.05$ \\
\hline Locations*temperature*salinity & 3 & 13148 & 135 & 345455 & $<0.05$ \\
\hline
\end{tabular}

TABLE 4

Median of $C$. concholepas EV larvae size found at the surface and at $8 \mathrm{~m}$ depth at each location. $\mathrm{N}=$ number of replicates; $\mathrm{U}=$ Mann-Whitney statistic; $\mathrm{P}$ = probability

Tabla 4: Mediana de los tamaños de larvas tempranas de $C$. concholepas encontradas en superficie y $8 \mathrm{~m}$ de profundidad en cada sector. $\mathrm{N}$ = número de muestras, $\mathrm{U}=$ Estadígrafo de Mann-Whitney, $\mathrm{P}$ = probability

\begin{tabular}{|c|c|c|c|c|c|c|}
\hline \multirow[t]{2}{*}{ Location } & \multicolumn{2}{|c|}{ Median $(\mu \mathrm{m})$} & \multicolumn{2}{|c|}{$\mathrm{N}$} & \multirow[t]{2}{*}{ U-value } & \multirow[t]{2}{*}{ P-value } \\
\hline & Surface & $8 \mathrm{~m}$ & Surface & $8 \mathrm{~m}$ & & \\
\hline RMB & 375 & 375 & 374 & 1078 & 190274 & 0.173 \\
\hline FRO & 366 & 350 & 821 & 3661 & 1304763 & 0.000 \\
\hline MEL & 366 & 344 & 1041 & 3795 & 1781061 & 0.000 \\
\hline GAL & 412 & 400 & 646 & 1551 & 435742 & 0.000 \\
\hline
\end{tabular}


cases median $=354 \mu \mathrm{m})$. Analysis by month showed significant differences in EV larval sizes at all locations (Kruskal-Wallis test, RMB: $\mathrm{H}_{13}$, $1442=149.7, \mathrm{P}<0.0001$; FRO: $\mathrm{H}_{13,4482}=693.4$, $\mathrm{P}<0.0001$; MEL: $\mathrm{H}_{13,4836}=892.9, \mathrm{P}<0.0001$; GAL: $\left.\mathrm{H}_{12,2197}=211.9, \mathrm{P}<0.0001\right)$, with a progressive increase in size from August to December (Fig. 5), while, we did not observe a clear trend from January to April.

CV larval sizes were similar from June to August at FRO (Mann-Whitney U-test, $\mathrm{U}_{1,2,11}$ $=4.5, \mathrm{P}=0.19$ ) and GAL (Kruskal-Wallis test, $\left.\mathrm{H}_{2,31}=5.4, \mathrm{P}=0.068\right)$, but differed between months at MEL (Kruskal-Wallis test, $\left.\mathrm{H}_{2,34}=15.6, \mathrm{P}=0.0004\right) . \mathrm{CV}$ larvae collected at GAL and MEL were similar in size and they were significantly larger than those collected at FRO (Kruskal-Wallis test, $\mathrm{H}_{2,78}=$
12.8, $\mathrm{P}=0.018$; Fig. 6). Nine months elapsed between the first peak of EV larval abundance (September) and the first record of CV larvae (June), while five months elapsed from the last peak of EV larval abundance (January) and the first record of CV larvae.

\section{Settlement}

Settlement was observed only during August at RMB, MEL and GAL. Unfortunately, the plaques installed at FRO were lost. A total of 69 settlers were found during this study. Significant differences were observed in settlers' abundances at RMB and MEL versus GAL (Kruskal-Wallis test, $\left.\mathrm{H}_{2,132}=46.9, \mathrm{P}<0.0001\right)$, whereas no significant differences were observed among depths in all locations (Kruskal-Wallis test, RMB,
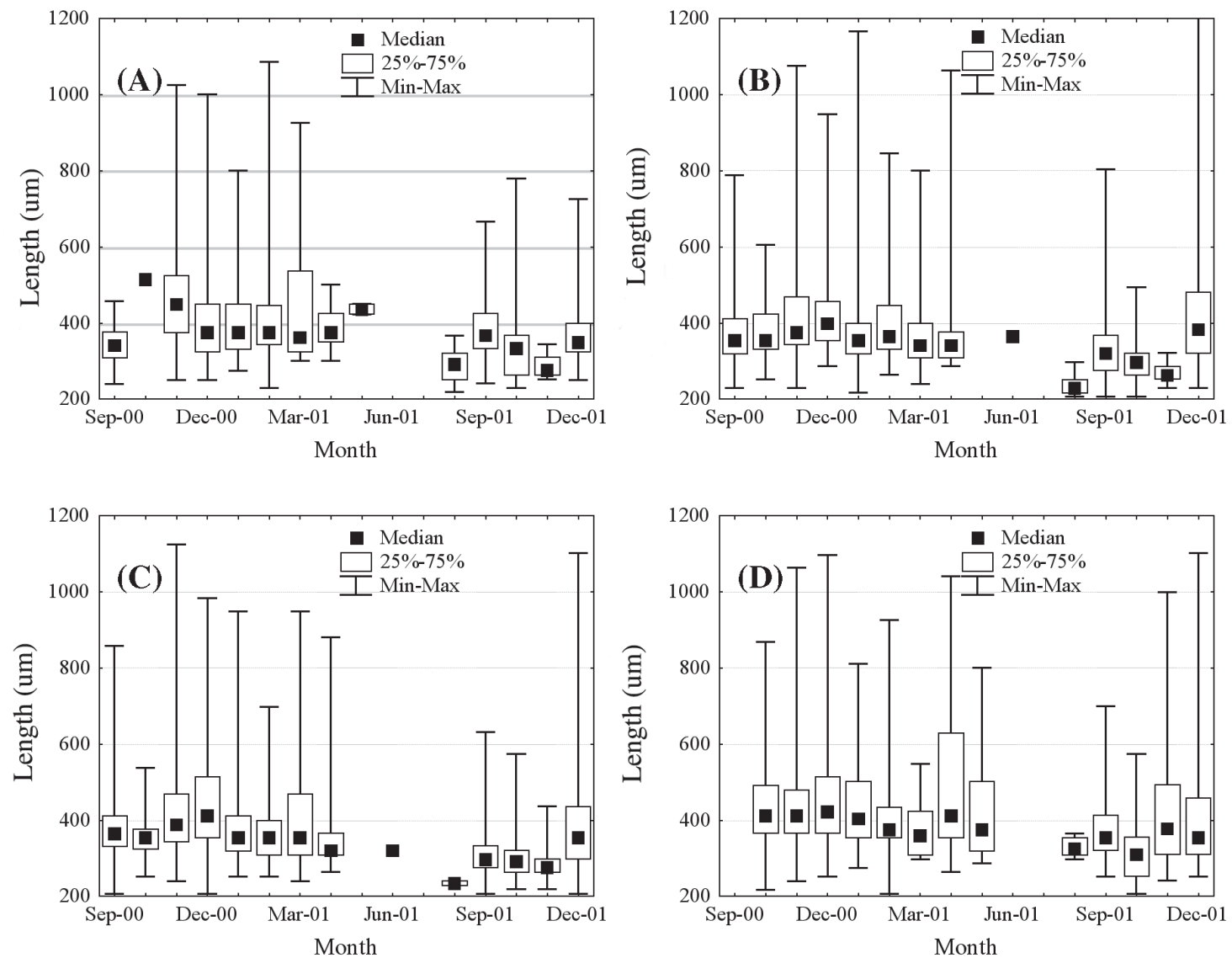

Fig. 5: EV larval length of $C$. concholepas collected at the surface and at $8 \mathrm{~m}$ depth between September 2000 and December 2001. (A) RMB, (B) FRO, (C) MEL, and (D) GAL.

Longitud de larvas tempranas de $C$. concholepas recolectadas entre septiembre de 2000 y diciembre de 2001. (A) RMB, (B) FRO, (C) MEL y (D) GAL. 

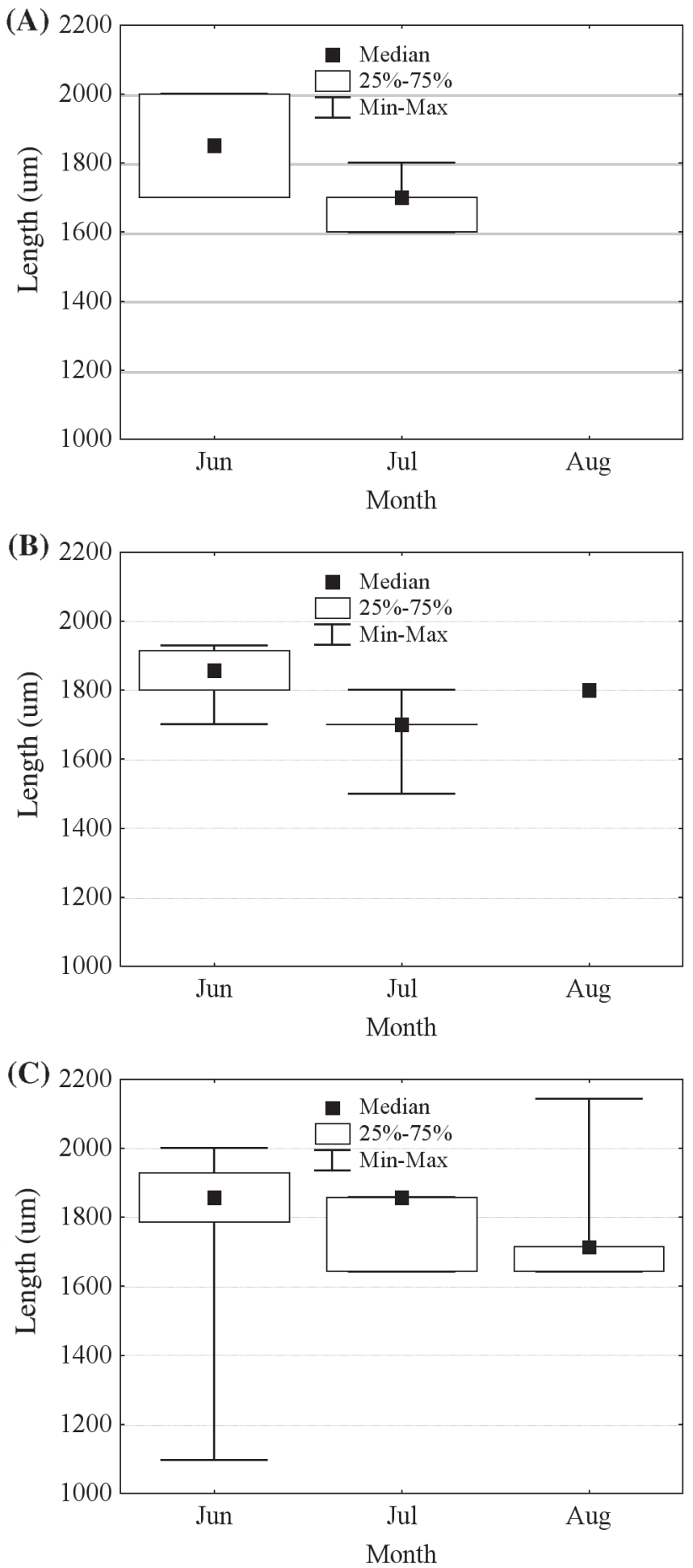

Fig. 6: CV larval length of C. concholepas collected between June and August of 2001. (A) FRO, (B) MEL, and (C) GAL.

Longitud de larvas competentes de C. Concholepas recolectadas entre junio y agosto de 2001. (A) FRO, (B) MEL y (C) GAL. 
$\mathrm{H}_{2,30}=1.0, \mathrm{P}=0.6 ; \mathrm{Mel}, \mathrm{H}_{2,34}=1.5, \mathrm{P}=0.5 ;$ and GAL, $\mathrm{H}_{2,30}=4.4, \mathrm{P}=0.1$ ) (Table 5).

\section{Salinity and temperature}

During the study period, strong variations in salinity were recorded at the surface in all locations (salinities ranged from 5 to $30 \mathrm{psu}$ ), except at GAL where observed salinity ranged between 20 and 30 psu (Fig. 7). Salinity values were lower at the surface than they were at $8 \mathrm{~m}$ depth, where ranged between 15 and 31 psu at FRO and MEL, and between 20 and 35 psu at $\mathrm{RMB}$ and GAL. Continuous salinity stratification was recorded at RMB between the surface and $8 \mathrm{~m}$ depth throughout the study period (Fig. 7A). Temperature ranged between 8 and $15{ }^{\circ} \mathrm{C}$ and showed a marked seasonality. Recorded temperatures were higher at RMB and GAL by ca. $0.5^{\circ} \mathrm{C}$ than they were at MEL and FRO (Fig. 7). The Spearman correlation indicates that both EV larval sizes and abundances show a positive significant relationship with temperature, but not with salinity (Fig. 8). However, we observed that EV larval abundances were low when salinity was less than 15-20 psu (Fig. 8C).

\section{DISCUSSION}

Planktonic larval development of $C$. concholepas occurs during the entire year in the fiords and channels investigated in this study. There appears to be continuous larval release from midwinter to early autumn which coincides with the capsular release of $C$. concholepas reported in south-central and northern Chile (Castilla \& Cancino 1976,
Ramorino 1979), and exceeds the period of release reported in southern Chile (Ibáñez 1992). The first early veliger larvae are released around August, while competent larvae were found from June until to August, suggesting a long period of larval development, lasting between 6 and 12 months. This significantly exceeds the duration of larval development reported by Disalvo (1988). The difference could be explained by the observation of lower seawater temperatures in the inland seas than those reported by Disalvo (1988). Lower temperatures and reduced food availability are believed to influence larval development in nature (Thorson 1950, Levin \& Bridges 1995).

Estimates of larval growth rates through modal cohort monitoring were not possible because of the long period of $C$. concholepas larval release, although larval sizes differed significantly among months, supporting the hypothesis of a temporal pattern of planktonic larval development starting between July and August and finishing between July and August of the following year. The distribution of smaller and intermediate sized EV larvae $(<$ $1,000 \mu \mathrm{m})$, either at the surface or at $8 \mathrm{~m}$ depth, suggests that these larvae are mainly planktonic, which does not agree well with the hypothesis of development in deeper waters, as proposed by Moreno et al. (1993). Large EV larvae $(>1,000 \mu \mathrm{m})$ were scarce despite the intensive sampling effort at the study sites. Further studies are needed to evaluate the importance of natural mortality during larval development in this species since high mortality has been observed in the laboratory (Disalvo 1988), and has been hypothesized (Scheltema 1986) for any larvae spending long

TABLE 5

Mean, minimum (min), and maximum (max) abundance of $C$. concholepas settlers observed during August 2001 at three depths on artificial substrates. (A) RMB, (B) MEL, (C) GAL

Promedio de la abundancia, mínimo (min) y máximo (máx) de asentados de $C$. concholepas recolectados a tres profundidades en sustratos artificiales durante agosto de 2001. (A) RMB, (B) MEL, (C) GAL

\begin{tabular}{|c|c|c|c|c|c|c|c|c|c|}
\hline \multirow[b]{2}{*}{ Locality } & \multicolumn{3}{|c|}{ Surface } & \multicolumn{3}{|c|}{$0.3 \mathrm{~m}$ depth } & \multicolumn{3}{|c|}{$6 \mathrm{~m}$ depth } \\
\hline & Mean & Min & Max & Mean & Min & Max & Mean & Min & Max \\
\hline GAL & 3.6 & 0 & 9 & 1.4 & 0 & 6 & 1.2 & 0 & 3 \\
\hline MEL & 0.1 & 0 & 1 & 0.1 & 0 & 1 & 0.3 & 0 & 1 \\
\hline RMB & 0 & 0 & 0 & 0.1 & 0 & 1 & 0.1 & 0 & 1 \\
\hline
\end{tabular}


A)

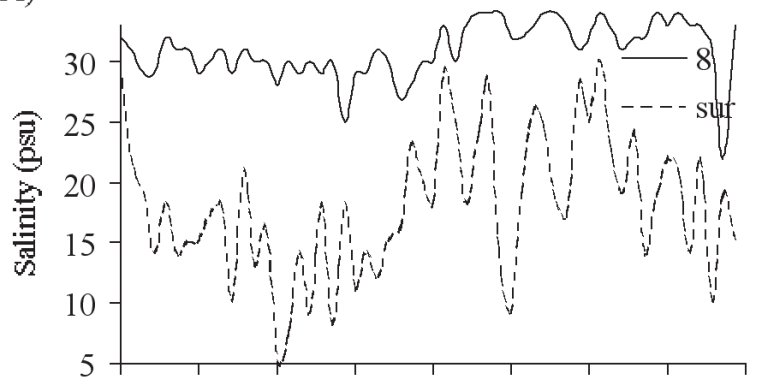

B)

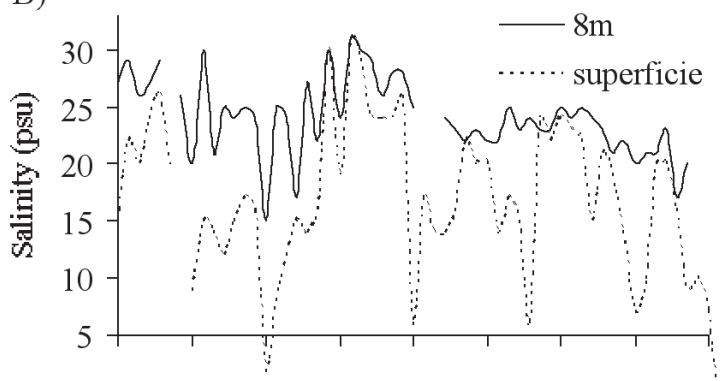

C)

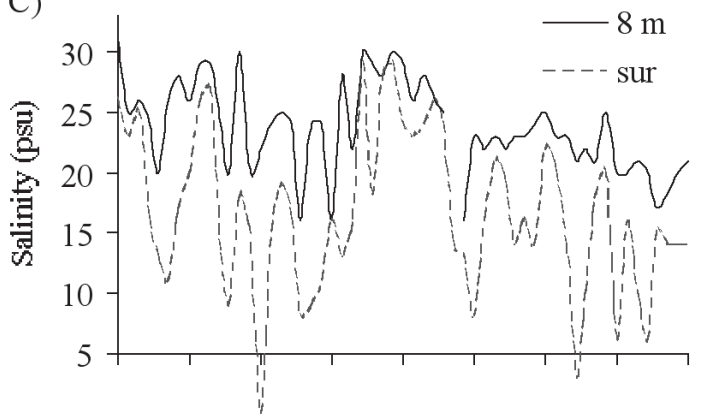

D)

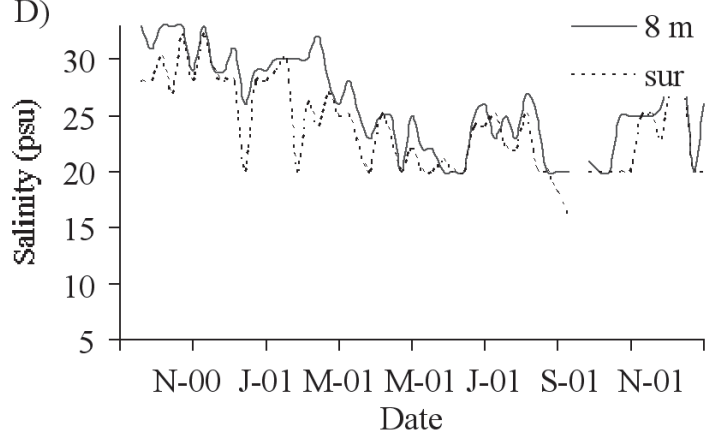

E)

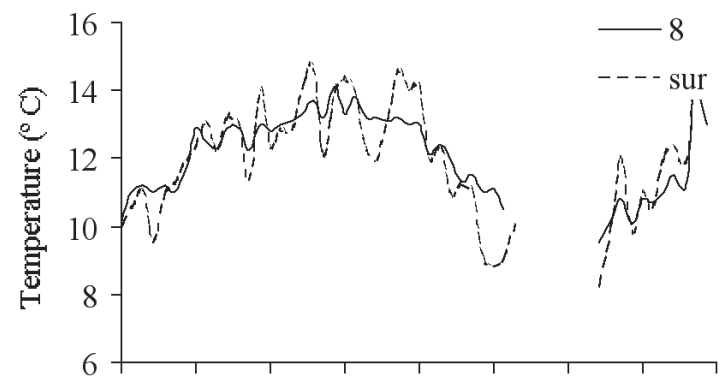

F)
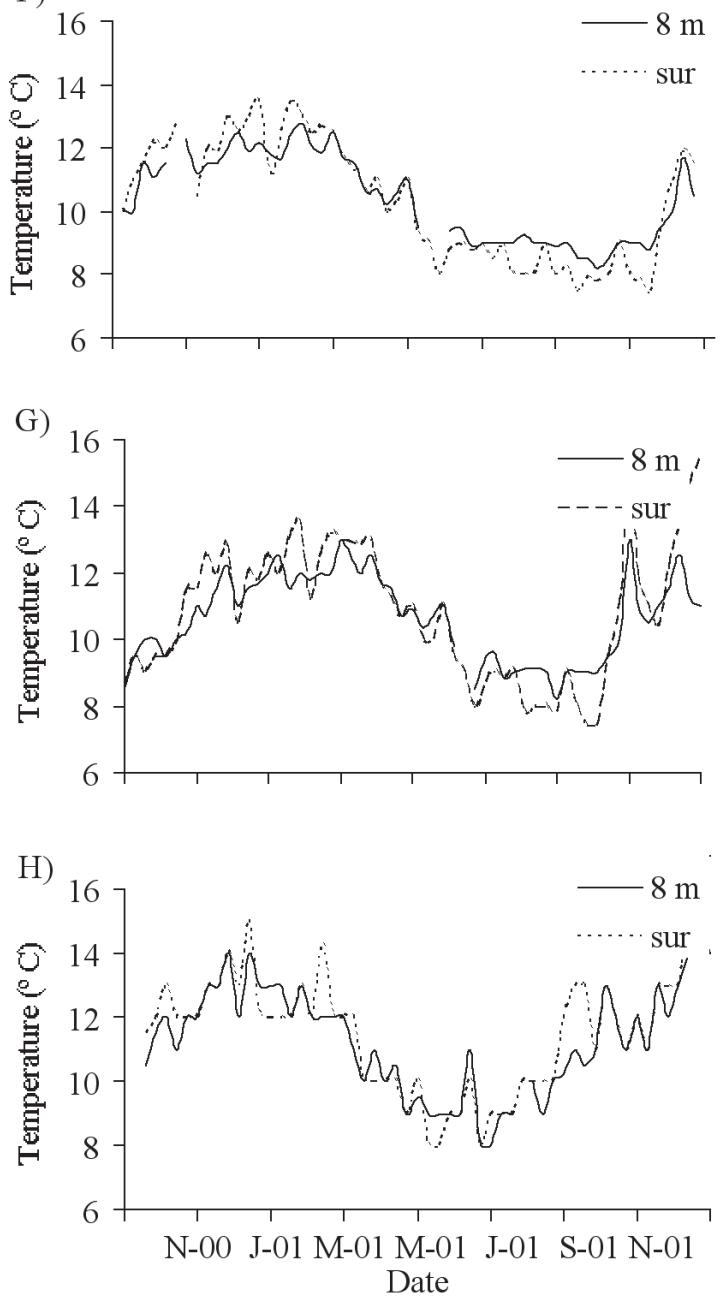

Fig. 7: Mean temperatures and salinities, recorded weekly in each study area throughout the study period. Right, salinity in psu; Left, temperature in ${ }^{\circ} \mathrm{C}$. (A) RMB, (B) FRO, (C) MEL and (D) GAL.

Promedio de temperatura y salinidad registrado semanalmente en cada área de estudio. Derecha salinidad en psu; izquierda, temperatura en ${ }^{\circ} \mathrm{C}$. (A) RMB, (B) FRO, (C) MEL y (D) GAL. 

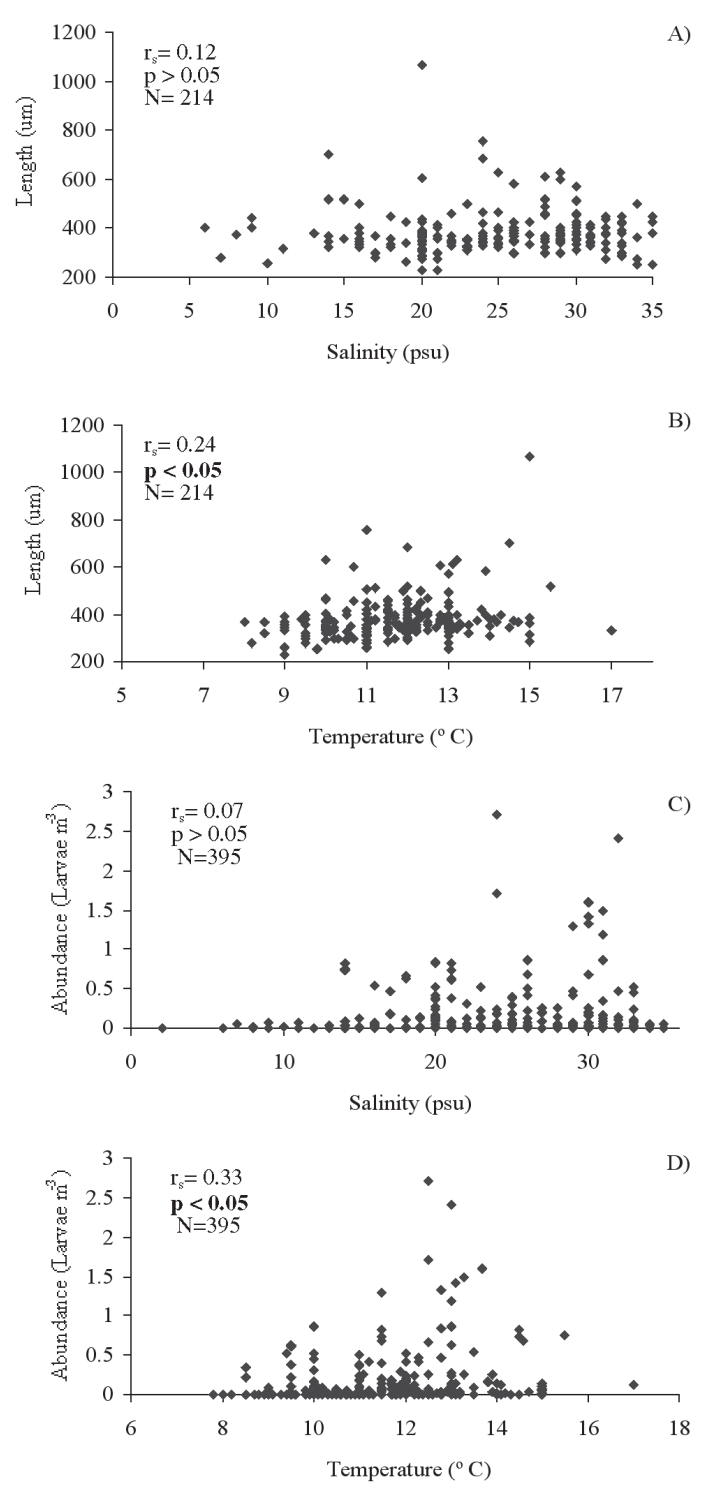

Fig. 8: Sizes and abundances of $C$. concholepas veliger larvae and their relationships with salinity and temperature at all locations: (A) relationship between median larval size and salinity, (B) relationship between median larval size and temperature, $(\mathrm{C})$ relationship between median larval abundance and salinity, and (D) relationship between median larval abundance and temperature. $\mathrm{r}=$ Spearman correlation, $\mathrm{P}=$ probability, $\mathrm{N}=$ sample size.

Tamaños y abundancias de larvas veliger de $C$. concholepas y su relación con salinidad y temperatura en todos los sectores: (A) Relación entre la mediana del tamaño larval y temperatura; (B) Relación entre la mediana del tamaño larval y salinidad; (C) Relación entre la mediana de la abundancia larval y salinidad; y (D) Relación entre la mediana de la abundancia larval y temperatura. $r=$ Correlación de Spearman, $\mathrm{P}=$ probabilidad, $\mathrm{N}=$ tamaño de la muestra. periods in the plankton. Also the studied depth range of larval distribution must to be extended in order to assess the entire distributional range of these larvae. By contrast, CV larvae were more abundant than larger EV larvae, being found mainly in surface samples, corroborating previous studies in which CV larvae were found only at the surface (Moreno et al. 1993, Peña et al. 1994, Poulin et al. 2002a, 2002b). Accumulation of $C$. concholepas $\mathrm{CV}$ larvae at the surface could explain in part why CV larvae were found to be more abundant than large EV larvae (see also Poulin et al. 2001b).

Differences in larval sizes were significantly explained principally by temperature, location and the interaction between location and temperature, suggesting an effect of local hydrology on larval size. Although field studies have shown the potential for plankton retention zones in fiords of southern Chile (Cáceres \& Valle-Levinson 2004) and other studies in North America and New Zealand have shown that larval retention can be produced by local hydrology (Wing et al. 1995, Churchill et al. 1999, Sköld et al. 2003, Wing et al. 2003), further investigations are needed to directly assess these effects in the inland seas of Chile.

Our results show strong influences of month and depth on EV larval abundance, although larval abundance observed at $8 \mathrm{~m}$ depth could be underestimate (C. Molinet unpublished data). The influence of month on larval abundance suggests a pattern of larval release and development that could be strongly influenced by seasonality.

Salinity was not correlated with larval abundance of $C$. concholepas, although EV larvae were more abundant when salinities exceeded ca. 15 psu, and CV larvae were not observed when salinities were less than ca. 15 psu. This suggests that $C$. concholepas veliger larvae have a salinity threshold, around 15-20 psu, below which their development could be constrained, as has been reported for other freeliving planktonic larval stages (Levin \& Bridges 1995). Also, larvae could avoid low salinity or the flow associated with low salinity could keep larvae out of the area. The effect of the continuous stratification observed at RMB on epineustonic CV larval distribution must be studied in order to explain the absence of these larvae in plankton samples collected in this 
area. Concholepas concholepas settlers were observed in concordance with the presence of CV larvae in all locations as observed by Moreno et al. (1993) and Martínez \& Navarrete (2002), although CV larval abundances were not coincident with the abundances of settlers on the plaques. This discrepancy may have resulted from a mismatch between weekly plankton sampling and monthly settlement sampling.

The highest abundances of settlers coincided with high and stable salinity values at GAL, suggesting that local differences in salinity oscillation, typically observed in these channels, could have great importance in the success of settlement. Settlement results suggest that $C$. concholepas can settle in subtidal zones, in agreement with the observations by Manriquez et al. (2004), although most previous records of settlement were in the intertidal zone (Stotz et al. 1991, Moreno et al. 1993, Martínez \& Navarrete 2002).

Concholepas concholepas planktonic larval development was observed to occur throughout the year in Chilean inland seas, with early veliger larvae being released mostly from August to March, reaching the competent stage around June to August, and having a long planktonic larval development that could last between 6 and 12 months. Differences in local hydrology could affect larval development of C. concholepas in this region. Further investigation is necessary in order to answer the questions raised by this study.

\section{ACKNOWLEDGEMENTS}

The authors wish to express their gratitude to the technicians of Santo Domingo, Raúl Marín Balmaceda and Gala. The Scientific and Technological Development Fund (FONDEF) of Chile provided financial support for this research. The first author is a student in the Science Doctorate Program and received support from the National Commission for Scientific and Technological Research (CONICYT) of Chile.

\section{LITERATURE CITED}

CÁCERES M \& A VALLE-LEVINSON (2004) Transverse variability of flow on both sides of a sill/contraction combination in a fjord-like inlet of southern Chile. Estuarine, Coastal and Shelf Science 60: 325-338.

CASTILLA JC \& J CANCINO (1976) Spawing behaviour and egg capsules of Concholepas concholepas (Mollusca: Gastropoda: Muricidae). Marine Biology 37: 255-263.

CASTILLA JC \& LR DURÁN (1985) Human exclusion from the rocky intertidal zone of central Chile: the effects on Concholepas concholepas (Gastropoda). Oikos 45: 391-399.

CHURCHILL JH, JO BLANTON, JL HENCH \& FE WERNER (1999) Flood tide circulation near Beaufort inlet, North Carolina: implication for larval recruitment. Estuaries 22: 1057-1070.

CONNELL JH (1985) The consequences of variation in initial settlement vs. postsettlement mortality in rocky intertidal communities. Journal of Experimental Marine Biology and Ecology 93: 11-45.

DISALVO LH (1988) Observations on the larval and postmetamorphic life of Concholepas concholepas (Bruguière, 1789) in laboratory culture. The Veliger 30: 358-368.

DISALVO LH \& MR CARRIKER (1994) Planktonic, metamorphic, and early benthic behavior of the Chilean loco Concholepas concholepas (Muricidae, Gastropoda, Mollusca). Journal of Shellfish Research 13: 57-66.

EMERY WJ \& RE THOMSON (1997) Data analysis methods in physical oceanography. Pergamon Press, ciudad, Great Britain. 634 pp.

GALLARDO C (1973) Desarrollo intracapsular de Concholepas concholepas (Bruguiere)(Gastropoda, Muricidae). Museo Nacional de Historia Natural (Chile) 16: 1-16.

IBÁÑEZ S (1992) Patrones de ocurrencia y abundancia de C. concholepas (Bruguiere) y otros zooplanctes en aguas costeras de la provincia de Valdivia, $\mathrm{X}$ región. Tesis de Grado, Facultad de Ciencias, Universidad Austral de Chile, Valdivia, Chile. 52 pp.

JOHNSON KB \& AL SHANKS (2003) Low rates of predation on planktonic marine invertebrate larvae. Marine Ecology Progress Series 248: 125-139.

LEIVA G \& JA CASTILLA (2002) A review of the world marine gastropd fishery: evolution of catches, management and the Chilean experience. Fish biology and Fisheries 11: 283-300.

LEVIN LA \& TS BRIDGES (1995) Pattern and diversity in reproduction and development. In: McEdward L (ed) Ecology of marine invertebrate larvae: 1-48. CRC Press, Boca Ratón, Florida, USA.

MANRÍQUEZ PH, SA NAVARRETE, A ROSSON \& JC CASTILLA (2004) Settlement of the gastropod Concholepas concholepas on shells of conspecific adults. Journal of the Marine Biology Association of the United Kingdom 84: 651-658.

MARTÍNEZ P \& SA NAVARRETE (2002) Temporal and spatial variation in settlement of the gastropod Concholepas concholepas in the natural and artificial substrata. Journal of the Marine Biology Association of the United Kingdom 82: 257-264.

MORENO CA, G ASENCIO \& S IBÁÑEZ (1993) Patrones de asentamiento de Concholepas concholepas (Brugiere) (Mollusca: Muricidae) en la zona intermareal rocosa de Valdivia, Chile. Revista Chilena de Historia Natural 66: 93-101.

MORENO CA, KM LUNECKE \& MI LÉPEZ (1986) The response of an intertidal Concholepas concholepas (Gastropoda) population to protection from man in southern Chile and the effects on benthic sessile assemblages. Oikos 46: 359-364. 
MORGAN ST (1995) Life and dead in the plankton: larval mortality and adaptation. In: McEdward L (ed) Ecology of marine invertebrate larvae: 279-322. CRC Press, Boca Ratón, Florida, USA.

PANFILI J, JD DURAND, A MBOW, B GUINAND, K DIOP, J KANTOUSSAN, D THIOR, OT THIAW, JJ ALBARET \& R LAË (2004) Influence of salinity on life history traits of the bonga shad Ethmalosa fimbriata (Pisces, Clupeidae): comparison between the Gambia and Saloum estuaries. Marine Ecology Progress Series 270: 241-257.

PEÑA G, P HUEPE, I LÉPEZ, O ARACENA, O OLIVARES \& C SANTOS (1994) Registro de larvas de Concholepas concholepas en el plancton costero de Bahía San Vicente y Coliumo, VIII Región. Boletín de la Sociedad de Biología de Concepción (Chile) 65: 81-87.

PICKARD GL (1971) Some physical oceanographic feactures of inlets of Chile. Fisheries Research Board of Canada 28: 1077-1106.

PINTO A, R VEGA \& V VIDELA (1993) Loco (Concholepas concholepas) IV etapa. Investigaciones Específicas: 30-36. CORFO/IFOP, Valparaíso, Chile.

POULIN E, AT PALMA, G LEIVA, E HERNÁNDEZ, P MARTÍNEZ, SA NAVARRETE \& JA CASTILLA (2002a) Temporal and spatial variation in the distribution of epineutonic competent larvae of Concholepas concholepas along the central coastal of Chile. Marine Ecology Progress Series 229: 95104.

RAMORINO L (1979) Conocimiento científico actual sobre reproducción y desarrollo de Concholepas concholepas (Mollusca: Gastropoda: Muricidae). Biologia Pesquera (Chile) 12: 59-70.

REYES AE \& CA MORENO (1990) Asentamiento y crecimiento de los primeros estadios bentónico de Concholepas concholepas (mollusca: Muricidae) en el intermareal rocoso de Mehuín,
Chile. Revista Chilena de Historia Natural 63: 157-163.

SILVA N, HA SIEVERS \& R PRADO (1995) Características oceanográficas y una proposición de circulación para algunos canales Australes de Chile entre $41^{\circ} 20^{`} \mathrm{~S}$ y $46^{\circ} 40^{\prime} \mathrm{S}$. Revista de Biología Marina de la Universidad Católica de Valparaíso (Chile) 30: 207-254.

SKÖLD M, SR WING \& PV MLADENOF (2003) Genetic subdivision of a sea star with high dispersal capability in relation to physical barriers in a fjordic seascape. Marine Ecology Proggress Series 250: 163-174.

STOTZ WB, DA LANCELLOTTI, DJ MARTÍNEZ, P DE AMESTI \& E PÉREZ (1991) Variación temporal y espacial del registro de juveniles recién asentados de Concholepas concholepas (Bruguiere, 789), en el intermareal rocoso de la IV Región, Chile. Revista de Biología Marina de la Universidad Católica de Valparaíso (Chile) 26: 351-361.

STUARDO J (1979) Sobre la clasificación, distribución y variación de Concholepas concholepas (Bruguiere 1789): un estudio de taxonomía Beta. Biología Pesquera (Chile) 12: 5-38.

THORSON G (1950) Reproductive and larval ecology of marine bottom invertebrates. Biological Reviews 25: 1-45.

VENABLES WN \& BD RIPLEY (1998) Modern Applied Statistics with S-Plus. Springer, New York., USA $548 \mathrm{pp}$.

WING SR, MT GIBBS \& MD LAMARE (2003) Reproductive sources and sink within a sea urchin Evechinus chlroticus population of a New Zealand fjord. Marine Ecology Proggress Series 248: 109-123.

WING SR, JL LARGIER, LW BOTSFORD \& JF QUINN (1995) Settlement and transport of benthic invertebrates in an intermittent upwelling region. Limnology and Oceanography 40: 316-329.

ZAR JH (1999) Biostatistical analysis. Prentice Hall, Englewood Cliffs, New Jersey, USA. 663 pp. 